\title{
Various Action Plans and Initiative Activities of NPCB
}

\section{Gaurav Dubey ${ }^{1}$, Dr Mahesh Chandra ${ }^{2}$, Vibha Kumari ${ }^{3}$, Jamshed Ali ${ }^{4 *}$, Dr Deepak Gupta ${ }^{5}$, Farzana Tairin Tusha ${ }^{6}$, SM Abdullah Al Mamun ${ }^{6}$, Sucheta Mitra ${ }^{7}$, Ragni Kumari ${ }^{8}$, Mantasha Dilkash ${ }^{9}$ and Yasmeen Shahid ${ }^{10}$}

${ }^{1}$ Department of Optometry, FPS, UPUMS Saifai Etawah, U.P, India

${ }^{2}$ Dr. Sushila Tewari Hospital and Govt. Medical College, Haldwani, Uttarakhand, India

${ }^{3}$ Department of Paramedical Sciences, Jamia Hamdard, New Delhi, India

${ }^{4}$ Department of Optometry, Allied Health Sciences, IIMT University, Meerut, U.P,

India

${ }^{5}$ Department of Optometry, National institute of Medical Sciences, Rajasthan,

Jaipur, India

${ }^{6}$ Chittagong Eye Infirmary and Training Complex, Bangladesh

${ }^{7}$ Department of Optometry, Arka Jain University, Jharkhand, India

${ }^{8}$ Amity Institute of Public Health, Amity University, Noida, U.P, India

${ }^{9}$ Department of Optometry, Dr. D. Y. Patil Institute of Optometry and Visual

Sciences, Pune, India

${ }^{10}$ Department of Optometry, TMU, Moradabad, U.P, India

*Corresponding Author: Jamshed Ali, Department of Optometry, College of Allied Health Sciences, IIMT University, Meerut, India.
Received: October 01, 2021

Published: October 09, 2021

(C) All rights are reserved by Gaurav Dubey., et al.

\begin{abstract}
India was the first country to launch the government-funded National Programme for Control of Blindness (NPCB) in 1976. A high percentage of blind people in a country is a sign of underdeveloped socioeconomic conditions and poor access to eye care. This is because 80-90 percent of blindness can be treated or prevented. Females, rural residents, and those who underwent cataract surgery later in life had worse visual outcomes than those who did not have these risk factors (more than 70 years). According to India's National Health Policy of 1983, lowering the prevalence of blindness from $1.4 \%$ to $0.3 \%$ was a top public health priority. By the end of the tenth five-year plan, the Indian government wants blindness to be reduced to 0.8 percent and 0.5 percent by 2010 . According to WHO, blindness is defined as vision loss of less than 10 degrees in the better eye with the best available correction or visual acuity of less than $3 / 60$. To reduce the frequency of blindness from $1.4 \%$ to $0.3 \%$.
\end{abstract}

Keywords: National Programme for Control of Blindness (NPCB); WHO; Blindness

\section{Introduction}

India was the first country to launch the government-funded National Programme for Control of Blindness (NPCB) in 1976 [1].
A high percentage of blind people in a country is a sign of underdeveloped socioeconomic conditions and poor access to eye care [2]. This is because $80-90$ percent of blindness can be treated or 
prevented [2]. Females, rural residents, and those who underwent cataract surgery later in life had worse visual outcomes than those who did not have these risk factors (more than 70 years). According to India's National Health Policy of 1983, lowering the prevalence of blindness from $1.4 \%$ to $0.3 \%$ was a top public health priority. By the end of the tenth five-year plan, the Indian government wants blindness to be reduced to 0.8 percent and 0.5 percent by 2010 . According to WHO, blindness is defined as vision loss of less than 10 degrees in the better eye with the best available correction or visual acuity of less than 3/60 [4]. To reduce the frequency of blindness from $1.4 \%$ to $0.3 \%$. According to a poll conducted in 2001-02, blindness will afflict $1.1 \%$ of the population. It was discovered by the NPCBVI's Rapid Survey on Avoidable Blindness in 2006-07 that the incidence of blindness has decreased from 1.1\% in 2001-02 to 1.0\%. (2006-07). Many actions and efforts were carried out during the NPCBVI; the Five-Year Plans aim to lower the incidence of blindness to $0.3 \%$ by 2020 [2]. School-age children have long been the most disadvantaged demographic. The refractive error may have a higher impact on learning capacity and, as a result, educational quotient than previously thought. As awareness camps and vision screenings get closer, data on the prevalence and frequency of refractive defects becomes increasingly important. Cataracts were the primary focus of the National Program for Control of Blindness (NPCB) until recently. In addition to the existing initiatives, it is now funding treatment for diabetic retinopathy (DR), glaucoma, eye trauma, childhood blindness, keratoplasty, squint, low vision, and retinopathy of prematurity (ROP) because to the effectiveness of public-private partnership arrangements (PPP). A fortnight-long campaign to promote eye donation/eye banking takes place every year between August -September. In terms of population, Gujarat is the largest state, followed by Tamil Nadu and Maharashtra. Blindness affects 45 million individuals worldwide, with 12 million of them living in India, where corneal blindness accounts for just 1\% [5]. The WHO predicts that by 2020, the number of blind people will have more than quadrupled due to population growth and longer life expectancy. Among the leading causes of blindness, Cataract's account for $62.6 \%$ of cases, followed by uncorrected refractive errors (19.7\%), Corneal Blindness (0.90\%), Glaucoma (5.80\%), and Surgical Complications (1.20 percent) (0.90\%), Posterior Capsular Opacification; (4.70\%) Posterior Segment Disorder; (4.19 percent) $[3]$.

\section{Goals of the Study}

- To minimize the prevalence of blindness.

- To develop an efficient infrastructure capable of handling a new instance of blindness each year to avoid future backlogs.

The objectives of the program are:

Boost and broaden Preventative blindness and visual impairment research.

Identify and cure blind people to reduce the number of people who are legally blind.

To create comprehensive eye care services in each district. We are expanding eye-care providers' human resources.

Expanding eye-care providers' human resources.

To ensure that eye care voluntary organizations and private practitioners are included.

To raise awareness about eye care services in the community.

To Secure participation of the voluntary organization.

Providing eye care services ensures everyone has access to healthy vision.

To provide the finest possible care for people with treatable forms of blindness in the area.

The framework for referral coordination and feedback across prevention, treatment, and rehabilitation-focused organizations should be established.

The NPCB grant was released to the State Blindness Control Society or the State Health \& Family Welfare Society in accordance with the annual action plan presented by the Government of India (GOI). India's top government body has approved an INR 12,500 (twelve thousand and five hundred) million budget, the Cabinet Committee on Economic Affairs, which Parliament set up. More than half of the preceding plan period's increased financing and financial allocation shows a strong political commitment [1].

Table 1: Objectives of NPCB [3].

\section{Program strategies}

Every year, India performs approximately 6 million cataract procedures, with a cataract surgery rate of 4800 per 10,000 people. From a low of 4.9 million in 2007, this number has progressively risen. It is estimated that over $95 \%$ of cataract surgeries are performed with microsurgical techniques like small incisions 
and extra-capsular cataract surgery (ECCE) with intraocular lens implant (IOL) [6]. Compared to previous procedures, the visual outcomes are light years better. Non-governmental organizations (NGOs) play a vital role in delivering eye care services in the country, and the public-private partnership model offers a variety of finance schemes.

\begin{tabular}{|l|}
\hline $\begin{array}{l}\text { Identifying and treating refractive problems in schoolchil- } \\
\text { dren through screening }\end{array}$ \\
\hline IEC activities for the community \\
\hline Strengthening of health care workers' capacity \\
\hline Public-private partnership involvement \\
\hline $\begin{array}{l}\text { Public-private partnership to provide eye care to } \\
\text { underprivileged areas }\end{array}$ \\
\hline Active surveillance of people above the age of 50 \\
\hline $\begin{array}{l}\text { Implementation of the plan must take place locally through } \\
\text { District Health Societies (NPCB) }\end{array}$ \\
\hline Cataract surgery for free should always be encouraged. \\
\hline Primary Eyecare is still a focus. \\
\hline $\begin{array}{l}\text { Better district eye care coverage with multipurpose mobile } \\
\text { ophthalmic units }\end{array}$ \\
\hline $\begin{array}{l}\text { Organized participation of rural institutions such as } \\
\text { communities and Panchayati raj }\end{array}$ \\
\hline
\end{tabular}

Table 2: Program Strategy.

Eye bank

Approximately 15 million Indians are blind, according to recent estimates. Corneal blindness affects 6.8 million people, and roughly 1 million of them have vision less than 6/60 in both eyes. If current trends continue, India's cornea blind population could reach 10.6 million people by 2020. Of these, corneal transplantation could help at least 3 million people. The NPCB currently reimburses Rs 2000/- for each pair of collected eyeballs under the current strategy. For established Government Eye Banks, NPCB additionally supports the purchase of equipment of Rs 25 lakh for equipment purchases and infrastructure development. This plan intends to promote the country's Eye banking activities by providing NGOs and other stakeholders with government facilities for acquiring adequate corneal tissue for transplantation.

\section{Development of human resource}

The education of ophthalmic surgeons and other medical professionals has remained a top concern to meet the country's growing need for eye care. Teachers, para-medical ophthalmic assistants, and medical officers are all trained as part of the curriculum to improve their jobs. During the $12^{\text {th }}$ Five Year Plan era under NPCB, it is intended to train 2500 eye surgeons from government hospitals in various sub-specialties of ophthalmology at 30 training facilities spread across the country [7].

\section{Information education and communication (IEC)}

Increasing community awareness about the eye is a major goal of the IEC program. NPCB disseminates IEC messages to the public using print, electronic, and social media. State governments design IEC strategies, which are then implemented at the district level. Among the local IEC, efforts are identifying, motivating potential beneficiaries, and informing them through media and teaching voluntary groups, teachers, and other community-based volunteers, such as ASHAs recognized under the National Rural Health Mission. The most successful approach to motivating the target demographic is interpersonal communication. A one-day orientation on the blind registry, motivation, and help for those afflicted can be delivered to selected individuals or organizations. PHC/CHC manages the orientation process.

\section{Organizational structure}

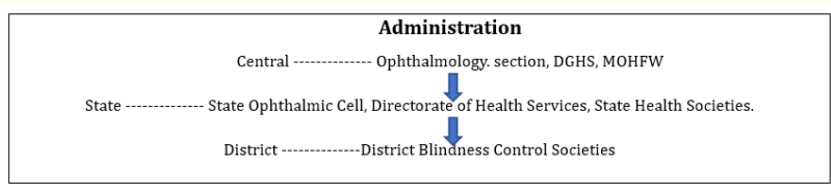

Figure 1: Organizational structure.

\begin{tabular}{|l|c|}
\hline Cataract operations & Involvement of NGOs \\
\hline Civil works & Commodity Assistant \\
\hline IEC activities & Management Information System \\
\hline Monitoring and Evaluation & School Eye Screening Programme \\
\hline $\begin{array}{l}\text { Collection and Utilization } \\
\text { of Donated Eyes }\end{array}$ & Control of Vitamin A deficiency \\
\hline
\end{tabular}

Table 3: ACTIVITIES of NPCB. 


\begin{tabular}{|l|c|}
\hline Telecast/Broadcast & Print Materials \\
\hline Postal and Railways & Display Messages/ Panels \\
\hline Video Messages & $\begin{array}{c}\text { Through NGOs and Stake } \\
\text { Holders }\end{array}$ \\
\hline Schools & Influential people \\
\hline SMS (new) & \\
\hline
\end{tabular}

Table 4: IEC Activities.

\section{Achievements of NPCB}

As a result of the school eye screening program's detection of refractive problems, 109189 instructors were trained, 30862970 students were screened, and 505398 students were provided with free glasses in 2009-10 [8]. According to recent reports [8], patients who have cataract surgery with Intra Ocular Lens implantation have better outcomes than those who undergo conventional surgery. Patients with poor visual results after cataract surgery needed close monitoring of their operated cases.

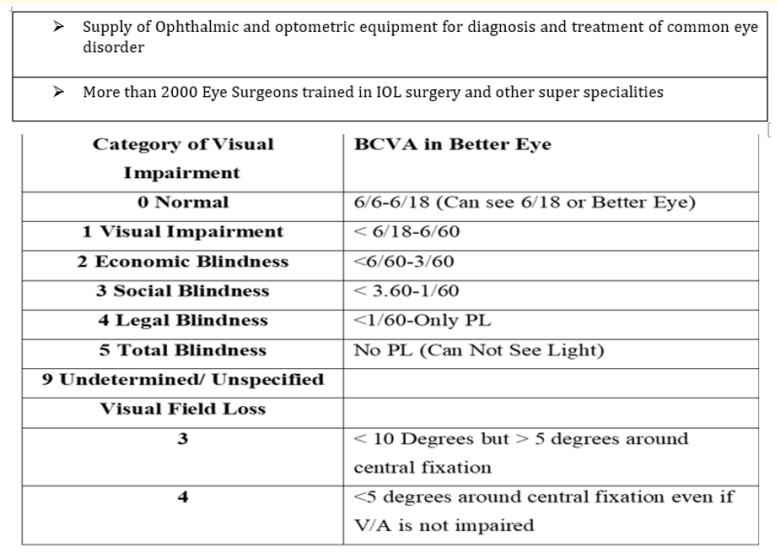

Figure 2: Categories of Visual Impairment.

\section{Vision. 2020.: The right. to sight}

An initiative that involves the entire world to end preventable blindness by 2020, VISION 2020 has set a goal of reducing it by half. It was founded on February $18^{\text {th }}, 1999$, by the International Agency for the Prevention of Blindness in collaboration with the

\begin{tabular}{|c|c|c|}
\hline & \multicolumn{2}{|c|}{ Plan of action for India } \\
\hline 1 & $\begin{array}{c}\text { Proposed structure } \\
\text { Centres of Excellence (20) } \\
\text { Training Centers (200) } \\
\text { Service Centers }(2000) \\
\text { Vision Centers }(20,000)\end{array}$ & Services at each centre \\
\hline & & $\begin{array}{l}\text { Primary level: vision centre } \\
\qquad 20,000 \\
\text { Screening and referral services } \\
\text { School eye screening program } \\
\text { Primary eye care } \\
\text { Refraction and prescription of } \\
\text { glasses } \\
\text { Secondary level: service centre } \\
\text { Cataract surgery } \\
\text { Other common eye surgeries } \\
\text { Facilities for refraction } \\
\text { Referral services }\end{array}$ \\
\hline & & $\begin{array}{c}\text { Tertiary level: } \\
\text { Training centre } 200 \\
\text { Retinal surgery } \\
\text { Corneal transplantation } \\
\text { Glaucoma surgery } \\
\text { Training and CME } \\
\text { Center of excellence 20: } \\
\text { Professional leadership } \\
\text { Strategy development } \\
\text { CME } \\
\text { Laying of standards and quality } \\
\text { assurance } \\
\text { Research }\end{array}$ \\
\hline
\end{tabular}

Table 5: Plan of action for India. 


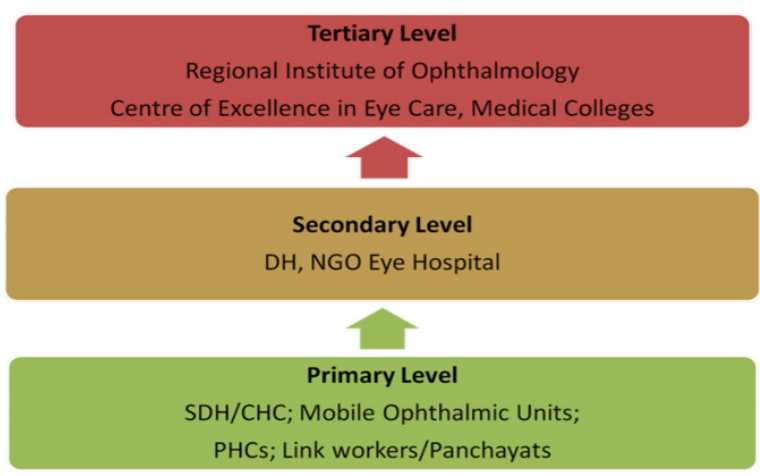

Figure 3: [Service. Delivery and Referral. system] [9].

World Health Organization and more than 20 international nongovernmental organizations (NGOs) engaged in eye therapy, prevention, and management of blindness (IAPB). VISION 2020 can provide guidance, strategic assistance, and resources to countries formally implementing the strategy. According to the VISION 2020 Global Initiative, the goal is to eliminate preventable and treatable causes of blindness in the developing world by 2020. Achieving three key goals is necessary for the Right to Sight to successfully reach its end aim.

Blindness control program (School eye screening among children in various age groups) [11]

The NPCB has been run predominantly by state governments in conjunction with district health authorities through public and non-governmental organizations since its foundation in 1976 by

Please increase the number of people aware of the causes of avoidable blindness and the solutions that can be used to eliminate it.

Locate and secure the funding required to offer more comprehensive prevention and recovery initiatives around the world.

Prepare, grow, and execute national programs with assistance from national programs. There are three key strategies for Vision 2020 [10].

Table 6: Vision 2020: the right to sigh.

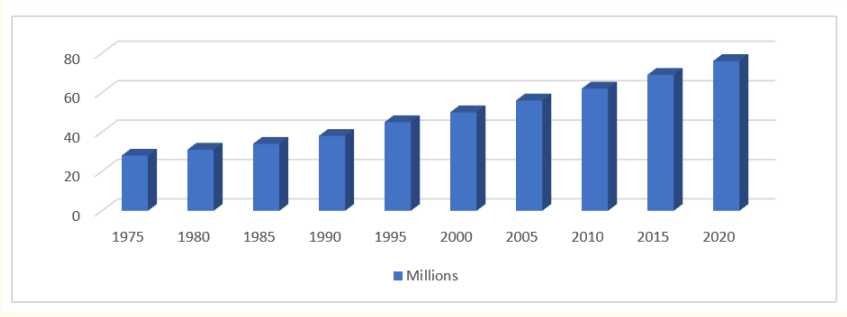

Figure 4: Vision 2020: The Right. to Sight. Trends \& Projection. in Global Blindness] [8].

India's Ministry of Health and Family Welfare. Various sources of funding are utilized, including public and private (NGOs). The NPCB accepted the School Eye Screening (SES) program in 1994 after five pilot districts had successfully implemented it. There will be screening for administrative, logistical, social, and medical reasons for kids in "middle and secondary schools," meaning schools with pupils in grades 5 [10]. Children aged 10 to 14 are well-versed on the purpose and significance of vision screening because of this. Students who are enrolled in these programs. It's simple to administer, and students may use it to spread awareness in their neighborhoods. A list of schools, student and teacher numbers, screening and referral centers, training for teachers and general health care personnel are all completed. Students who are deemed "suspicious" have their eyes examined by an ophthalmic assistant/ ophthalmologist, glasses are prescribed, and free glasses are distributed to those from low-income families who qualify for them. All these activities are a part of the SES program.

\section{Initiatives of the program}

Providing free glasses to presbyopic people.

Providing school children with eyeglasses during an annual Eye Testing Fortnight in June

Providing MDMOUs (Multipurpose District Mobile Ophthalmic Units) in all the country's municipalities.

To raise awareness about eye donation and encourage eye banks to do a better job in the years to come.

Hospital cornea retrieval program - including a mandatory request for eye donation in cause of death certificates given by hospitals must be implemented firmly (NPCB quarterly newsletter July-sept. 2012) 


\begin{tabular}{|l|}
\hline $\begin{array}{l}\text { In places where there aren't any, appointing Ophthalmic } \\
\text { Assistants (at present ophthalmic assistants are available in } \\
\text { block-level PHCs only) }\end{array}$ \\
\hline $\begin{array}{l}\text { Government and non-governmental organizations may hire } \\
\text { eye donation counsellors on a contract basis at eye banks. }\end{array}$ \\
\hline $\begin{array}{l}\text { Develop Mobile Ophthalmic Units to diagnose and treat eye } \\
\text { problems in the Northeast, Hilly States, and Difficult Ter- } \\
\text { rains. }\end{array}$ \\
\hline $\begin{array}{l}\text { Emphasis on clearing the cataract backlog while also attend- } \\
\text { ing to the needs of eye care facilities in the north-eastern } \\
\text { states. }\end{array}$ \\
\hline $\begin{array}{l}\text { Eye Care Management Information and Communication } \\
\text { Network in Telemedicine in Ophthalmology }\end{array}$ \\
\hline $\begin{array}{l}\text { Sub-district, block, and village involvement of private prac- } \\
\text { titioners. }\end{array}$ \\
\hline $\begin{array}{l}\text { Constructing specialized Eye Wards and Operation Theatres } \\
\text { in North-Eastern States, Bihar, Jharkhand, Kashmir, Him- } \\
\text { achal Pradesh, Uttaranchal, and other States in response to } \\
\text { demand in districts and sub-district hospitals. }\end{array}$ \\
\hline $\begin{array}{l}\text { Appointment of ophthalmologists in new districts of district } \\
\text { and sub-district hospitals in the state. }\end{array}$ \\
\hline $\begin{array}{l}\text { Eye Care Management Information and Communication } \\
\text { Network in Telemedicine in Ophthalmology }\end{array}$ \\
\hline $\begin{array}{l}\text { Participation of private practitioners on a district, block, and } \\
\text { village-wide basis }\end{array}$ \\
\hline
\end{tabular}

Table 7: Initiatives of The Program.

\section{Conclusion}

Even though people are aware of blinding eye illnesses and the National Program for Control is readily available, it is misused. It affects individuals and the community's economy, both individually and collectively, because blindness is more than a social hindrance.

\section{Recommendation}

Our Vision is something that most of us tend to take for granted. Maintaining our eyesight is essentital and easy to do by maintaining a healthy deit. You can even grow most of these plants right in your own backyard. Eye heath can be promoted especially by intake of vitamin A, Vitamin B12, Vitamin C, Riboflavin, Lutein and Zeaxanthin.See all of the plants that you can grow that benefit your eye health, Citrus fruits (such as lemons,limes,oranges, and grapefruit) are a great addition to a diet to help promote eye health. These contain many antioxidats such as vitamin C. These hep to reduce your risk for developing cataracts and macular degeneration.

\section{Conflict of Interest}

Nil.

\section{Bibliography}

1. Park K. Park's Textbook of Preventive and Social Medicine. 20th ed. Jabalpur: Banarsidas Bhanot Publishers; 2009. Health programme in India (2009): 375.

2. National programme for control of blindness; Government of Orissa (2010).

3. Jose R. "Present Status of the National Programme for Control of Blindness in India". Community Eye Health Journal 21.65 (2008): 103-104.

4. Global Initiative for The Elimination of Avoidable Blindness Action Plan 2006-2011. Vision 2020 The Right to Sight (2007).

5. National programme for control of blindness. Guidelines for State health society and district health society revised 11th five-year plan (2009).

6. NPCB: Statistics.

7. Pattern of assistance for National Programme for Control of Blindness during XIIth five-year plan; 06th May 2013; Office memorandum No.G.20014/2/2013-BC, Ministry of Health and Family Welfare, Government of India, Nirman Bhawan, New Delhi (2013).

8. VISION 2020. The International Agency for the Prevention of Blindness (2021).

9. NPCBVI (2021).

10. What is vision 2020?. World Health Organization. World Health Organization (2010).

11. Jose R and Sachdeva S. "School eye screening and the National Program for Control of Blindness". Indian Pediatrics 46.3 (2009): 205-208.

Volume 4 Issue 11 November 2021 (C) All rights are reserved by Gaurav Dubey., et al. 